\title{
Bimbingan Penggunaan Kit Fluida Alternatif yang Berasal dari Sampah Anorganik Bagi Siswa SD Negeri 6 Mataram
}

\author{
Syahrial Ayub $^{1 *}$, Ni Nyoman Sri Putu Verawati ${ }^{1}$, Muhammad Zuhdi ${ }^{1}$ \\ ${ }^{\text {I} P r o g r a m ~ S t u d i ~ P e n d i d i k a n ~ I P A, ~ F K I P ~ U n i v e r s i t a s ~ M a t a r a m, ~ M a t a r a m, ~ I n d o n e s i a ~}$
}

DOI: https://doi.org/10.29303/jpmsi.v2i1.28

Citation: Ayub S., Verawati N. Y. S. P., Zuhdi M. 2020. Bimbingan Penggunaan Kit Fluida Alternatif yang Berasal dari Sampah Anorganik Bagi Siswa SD Negeri 6 Mataram . Jurnal Pengabdian Masyarakat Sains Indonesia (JPMSI). 2(1): 63-68.

\section{Article history}

Received: April, $13^{\text {th }} 2020$

Revised: April, $21^{\text {th }} 2020$

Accepted: April, $30^{\text {th }} 2020$

*Corresponding Author:

Syahrial Ayub,

FKIP Universitas Mataram,

Mataram, Indonesia; Email:

syahrial_ayub@unram.ac.id

\begin{abstract}
Abstrak: Kegiatan pengabdian ini bertujuan memberikan bimbingan penggunaan kit fluida alternatif pada pembelajaran IPA. Kit fluida alternatif ini dibuat dengan memanfaatkan sampah anorganik yang sudah tidak digunakan. Sampah anorganik adalah sampah yang dihasilkan dari bahan-bahan non-hayati, baik berupa produk sintetik maupun hasil proses teknologi pengolahan bahan tambang atau sumber daya alam dan tidak dapat diuraikan oleh alam, seperti botol plastik, tas plastik, kaleng dan lain-lain. Alat-alat yang terdapat pada kit fluida alternatif adalah alat peraga kapal selam sederhana, alat peraga aliran air, alat peraga tekanan hidrostatis, alat peraga kincir air sederhana, alat peraga tekanan udara luar, alat peraga pompa air tekanan udara, alat peraga barometer botol, alat peraga telur ajaib, alat peraga roket tekanan udara dan alat peraga helikopter sederhana. Alat-alat peraga ini disusun dalam satu kotak dan mudah dibawa (portable). Kotak inilah yang disebut dengan kit fluida alternatif. Kit fluida ini diterapkan pada pembelajaran IPA di SD Negeri 6 Mataram. Respon peserta didik terhadap pembelajaran dengan integrasi kit fluida alternatif adalah $78 \%$ menyatakan sangat setuju dan hanya $22 \%$ yang menyatakan setuju dan tidak ada yang memilih tidak setuju. Berdasarkan data ini, disimpulkan bahwa kegiatan bimbingan penggunaan kit fluida alternatif di SD Negeri 6 Mataram mendapat respon yang baik dari siswa.
\end{abstract}

Kata kunci: Kit Fluida Alternatif, Sampah Anorganik, Pembelajaran IPA

\section{Pendahuluan}

Ilmuwan pada umumnya bekerja hanya menguasai sejumlah kemampuan atau keterampilan fisik dan mental tertentu saja. Kebanyakan ilmuwan justru mendapatkan penemuan baru tanpa menguasai semua fakta dan konsep yang terhimpun dalam suatu cabang atau disiplin ilmu. Penguasaan fakta dan konsep yang terlalu banyak dan mendalam justru menghambat daya ciptanya dengan menempatkan aktifitas nyata siswa untuk menemukan hal-hal yang baru (Klinger, 1997). Berdasarkan hal ini, maka dalam penyajian materi pelajaran hendaknya dirancang dan didesain untuk menambah rasa ingin tahu siswa. Rasa ingin tahu tersebut hendaknya dikembangkan untuk seluruh mata pelajaran. Belajar merupakan proses yang aktif yakni proses melihat, mengamati dan memahami sesuatu serta proses berbuat melalui pengalaman. Dengan kata lain dalam proses pengajaran yang menjadi persoalan utama adalah adanya proses berubahnya tingkah laku siswa melalui pengalaman yang diperolehnya. Pengajaran IPA yang utuh adalah pengajaran yang mengangkat tiga hakekat IPA, yakni mengembangkan pemahaman para peserta didik tentang alam, mengembangkan keterampilan-keterampilan yang diperlukan untuk memperoleh atau mengembangkan pengetahuan yang baru, dan mengembangkan sikap-sikap positif. Konsep, hukum dan teori tidak seharusnya diajarkan kepada siswa sebagai suatu pengetahuan yang diingat- 
Syahrial Ayub et al, Jurnal Pengabdian Masyarakat Sains Indonesia 2020, 2 (1): 63-68. DOI : https://doi.org/10.29303/ipmsi.v2i1.28

ingat, melainkan perlu diusahakan agar siswa juga belajar bagaimana mendapat pengetahuan dengan berbagai objek yang dipelajari baik di laboratorium, di kelas maupun di lingkungan sekolah.

Menurut (Semiawan, 1988), terdapat lima macam hasil belajar yakni informasi, keterampilan intelektual, strategi kognitif, sikap dan keterampilan motorik. Informasi verbal adalah informasi yang diperoleh dari kata yang diucapkan orang, informasi ini meliputi fakta-fakta atau konsepkonsep. Keterampilan intelektual meliputi bagaimana membedakan, menunjukkan suatu konsep konkrit. Strategi kognitif dalam pembelajaran IPA adalah membuat suatu perencanaan untuk memecahkan masalah. Sikap merupakan pembawaan yang dapat dipelajari, yang dapat mempengaruhi tingkah laku terhadap kejadian kejadian (Khaerudin, 2002). Sedangkan keterampilan motorik mencakup kegiatan-kegiatan fisik seperti berbicara, menulis dan menggunakan peralatan. Salah satu usaha dalam mencapai hasil belajar ini, adalah melalui pengadaan alat-alat peraga IPA (kit fluida). Untuk tidak menimbulkan keraguan perlu kiranya dirumuskan apa yang dimaksud dengan kit fluida. Kit berarti kotak, sehingga kit fluida dapat diartikan sebagai kotak yang berisi seperangkat alat-alat IPA. Dalam Webster's New Collegiate Dictionary dijelaskan bahwa: Kit is box, bag in which such a Kit is carried yang artinya Kit adalah kotak, tas tempat Kit dan mudah dibawa (Merriem, 1953).

Sehingga kit fluida dapat didefinisikan sebagai kotak yang berisi seperangkat alat-alat IPA tentang konsep fluida yang mudah dikemas dan dibawa ke dalam kelas saat mengadakan percobaan atau kegiatan belajar mengajar (KBM). Memanfaatkan kit fluida yang tersedia, siswa dapat berhadapan dengan peralatan secara langsung dan melakukan percobaan. Hal ini dapat memberikan manfaat yang cukup besar bagi siswa. Dimana, siswa dapat mencoba, mengalami dan berbuat sesuai dengan kegiatan yang dilakukan oleh ilmuwan ketika bekerja. Untuk membimbing dan mengarahkan siswa untuk melakukan percobaan, sangatlah diperlukan penuntun atau petunjuk yang berisi uraian singkat tentang apa yang harus dilakukan siswa. Melalui pembelajaran ini diharapkan dapat mengubah pola mengajar dari teacher oriented menjadi student oriented, mengembangkan keterampilan proses, mengembangkan sikap ilmiah, serta membangkitkan rasa cinta siswa terhadap alam
e-ISSN : 2715-2537 p-ISSN : 2715-2545

sekitar. Bila dikaji lebih mendalam, ternyata kit fluida banyak memberi keuntungan bagi siswa, seperti siswa dapat terlibat secara langsung dalam melakukan percobaan.

Hal ini merupakan pendekatan multisensorik dalam arti siswa dapat mendengar, melihat dan meraba, sehingga diharapkan dapat meningkatkan keterampilan dan menciptakan suasana yang akrab. Prestasi belajar merupakan akumulasi dari kesanggupan siswa untuk menyerap informasi yang diterimanya. Hasil yang diperoleh setiap siswa, dalam suatu mata pelajaran belum tentu sama. Kemampuan yang diharapkan dari diri siswa pada hakekatnya adalah prestasi belajar yang diinginkan. Prestasi belajar ini mencakup tiga domain, yaitu kognitif (penalaran), afektif (sikap) dan psikomotor (bertindak), (Winataputra, 1996). Prestasi belajar selayaknya memunculkan ketiga domain secara serentak. Ketiga domain ini, dapat diukur dengan melakukan tes terhadap siswa. Oleh karena itu, untuk mencapai ketiga domain tersebut, memanfaatkan penggunaan kit fluida dan alat sederhana merupakan jawaban yang tepat. Pengabdian ini merupakan pengembangan dari pengabdian yang telah dilakukan sebelumnya mengenai skenario pembelajaran yang berorientasi pada pemanfaatan kit fluida.

Berdasarkan pengabdian (Syahrial, 2003), penerapan model pembelajaran yang mengoptimalkan penggunaan kit fluida dapat meningkatkan keterampilan siswa dalam pemakaian alat percobaan IPA, dimana model pembelajaran yang berorientasi kepada siswa mendapat respon yang sangat baik dari siswa dan dapat meningkatkan prestasi belajar siswa. Kemudian dari hasil studi penggunaan kit IPA di kota Mataram ditemukan fakta bahwa jarangnya pemakaian kit fluida SD dalam pembelajaran di kelas (Syahrial, 2001).

Berdasarkan hasil monitoring yang dilakukan oleh Dirjen Pendidikan Dasar dan Menengah tahun 2000, ditemukan bahwa kit fluida belum digunakan dalam pembelajaran di kelas, hasil penataran belum diimplementasikan secara optimal dan kegiatan belajar mengajar (KBM) di kelas cenderung kembali ke pola sebelum penataran diberikan. Hal yang serupa, juga ditemukan di kota Mataram, Provinsi Nusa Tenggara Barat (NTB). Dari hasil pengabdian yang dilakukan oleh (Syahrial, 2001)., ditemukan fakta bahwa peralatan IPA yang ada di sekolah jarang digunakan oleh guru dalam KBM. Penyebabnya adalah guru pada umumnya kurang 
Syahrial Ayub et al, Jurnal Pengabdian Masyarakat Sains Indonesia 2020, 2 (1): 63-68. DOI : https://doi.org/10.29303/ipmsi.v2i1.28

menguasai konsep-konsep IPA dan cara merangkai percobaan IPA dengan kit dengan baik dan benar. Di samping itu, dari hasil observasi mengenai ketersediaan kit fluida untuk tingkat sekolah dasar (SD) di kota Mataram ditemukan bahwa 60\% sekolah belum mempunyai kit fluida.

Oleh karena itu perlu dipikirkan kit fluida alternatif dan alat sederhana yang dapat menggantikan kit fluida dan menanamkan konsep yang sama. Data statistik NTB melaporkan bahwa terdapat $58 \%$ guru yang tidak layak, dimana kelemahan terbesar terjadi pada sisi kompetensi kualitas pengajaran. Kelemahan ini dapat berpengaruh negatif terhadap komponen lain dalam sistem yang kolaboratif, sebab ketidakmampuan guru dalam mengajar sesuai dengan tuntutan kurikulum akan berakibat fatal bagi penanaman konsep-konsep dasar ke anak didik (Klinger, 1997).

Berdasarkan hal ini perlu usaha-usaha yang kongkrit dilakukan, salah satunya adalah mengembangkan kit fluida alternatif yang berasal dari sampah anorganik. Meningkatkan kualitas mengajar guru akan meningkat, salah satunya terdapat alat peraga atau alat-alat laboratorium. Mendapatkan alat laboratorium membutuhkan biaya yang mahal, sehingga pengabdian ini penting dilaksanakan. Rumusan masalah yang diajukan pada pengabdian ini, adalah sebagai berikut:

a. Bagaimana bentuk kit fluida alternatif untuk pembelajaran IPA?

b. Bagaimana desain percobaan IPA dengan memanfaatkan kit fluida alternatif yang berasal dari sampah anorganik untuk pembelajaran?

c. Bagaimana respon pesertadidik terhadap skenario pembelajaran IPA yang inovatif dan kit fluida alternatif yang berasal dari sampah anorganik serta integrasinya dalam pembelajaran IPA di SD?

\section{Metode}

Kegitan pengabdian ini, berlangsung 6 tahap, yaitu: (1) Mengumpulkan informasi pengetahuan awal siswa tentang kit fluida, (2) Merencanakan kegiatan pelatihan, (3) Membuat kit alternatif dari sampah anorganik, (4) Memberikan bimbingan penggunaak kit alternatif kepada siswa, (5) Menentukan respon siswa terhadap penerapan kita fluida alternatif, (6) Menarik kesimpulan dan merumuskan saran dari hasil kegiatan pengabdian. Pada tahap (1) dilakukan penggalian informasi tentang pengetahuan awal siswa tentang
e-ISSN : 2715-2537

p-ISSN : 2715-2545

penggunaan kit fluida. penerapan kit fluida pada pembelajaran dan studi tentang penggunaan kit fluida di sekolah. Data studi awal dan literatur ini akan menjadi informasi awal dalam mengembangkan kit fluida alternatif di sekolah dasar dan melakukan bimbingan, Tahap ke (2) berdasarkan studi awal dan literatur yang sudah dianalisis, tim merancang kit fluida alternatif yang bahan-bahannya berasal dari sampah anorganik. Setelah itu baru disusun desain awal kit fluida alternatif. Kemudian dirancang pelaksanaan kegiatan pelatihan. Tahap (3) bentuk permulaan kit fluida alternatif telah dibuat. Tahap (4) tim melakukan implementasi pembelajaran dan melakukan bimbingan dengan menggunakan Kit fluida alternatif dengan pedoman rencana pelaksanaan pembelajaran yang sudah dibuat. Pada tahap ini diperoleh data observasi pembelajaran, data evaluasi dan refleksi dari tim dan guru untuk implementasi berikutnya. Tahap (5) Tim menyebarkan angket respon penggunaan kit fluida alternatif kepada siswa. Tahap (6) Tim membuat kesimpulan dan merumuskan saran pada pihakpihak yang terkait bagi peningkatan kualitas pembelajaran IPA.

Berdasarkan aspek-aspek yang telah dijelaskan sebelumnya, maka dalam pengabdian ini akan dihasilkan: (a) percobaan dengan alat-alat sederhana yang berasal dari lingkungan dan dapat digunakan untuk pembelajaran IPA di SD, hal ini untuk mengantisipasi sekolah-sekolah yang belum memiliki kit fluida sehingga tidak menghalangi inovasi pembelajaran IPA. Temuan ini akan dibukukan sebagai pedoman bagi guru untuk membuatnya, (b) informasi tanggapan peserta didik terhadap inovasi pembelajaran IPA yang memanfaatkan kit fluida alternatif dan alat sederhana dari lingkungan.

Melalui pengisian kuesioner diperoleh data mengenai respon peserta didik terhadap penerapan skenario pembelajaran inovatif yang memanfaatkan kit fluida dan alat sederhana Kemudian data-data ini dianalisis secara deskriptif kualitatif dengan menggunakan skor dalam skala $1-5$, dimana skor 5 = sangat baik, $4=$ baik, $3=$ cukup, $2=$ kurang dan $1=$ sangat kurang. Skor maksimal setiap item adalah 5 sehingga dari 20 item diperoleh skor maksimal 100. Analisis data respon siswa menggunakan Mi dan Si. Rerata Mi dapat dihitung dengan: $\mathrm{Mi}=1 / 2$ (Skor maksimal ideal). Sedangkan simpangan ideal Si dapat dihitung dengan: $\mathrm{Si}=1 / 3$ 
Syahrial Ayub et al, Jurnal Pengabdian Masyarakat Sains Indonesia 2020, 2 (1): 63-68. DOI : https://doi.org/10.29303/ipmsi.v2i1.28

(Mi). Kriteria respon siswa ditentukan berdasarkan pedoman konversi berikut ini:

Tabel 1: Pedoman konversi penilaian skala 1-5

\begin{tabular}{|l|l|l|}
\hline & $\begin{array}{l}\text { Konversi } \\
\text { Nilai }\end{array}$ & Kriteria \\
\hline $\begin{array}{l}(\mathrm{Mi}+1,5 \mathrm{Si})-(\mathrm{Mi} \\
+3,0 \mathrm{Si})\end{array}$ & $76 \%-100 \%$ & $\begin{array}{l}\text { Sangat } \\
\text { baik }\end{array}$ \\
\hline $\begin{array}{l}(\mathrm{Mi}+0,5 \mathrm{Si})-(\mathrm{Mi} \\
+1,5 \mathrm{Si})\end{array}$ & $59 \%-75 \%$ & Baik \\
\hline $\begin{array}{l}(\mathrm{Mi}-0,5 \mathrm{Si})-(\mathrm{Mi} \\
+0,5 \mathrm{Si})\end{array}$ & $43 \%-58 \%$ & Cukup \\
\hline $\begin{array}{l}(\mathrm{Mi}-1,5 \mathrm{Si})-(\mathrm{Mi} \\
-3,0 \mathrm{Si})\end{array}$ & $25 \%-42 \%$ & Kurang \\
\hline $\begin{array}{l}(\mathrm{Mi}-3,0 \mathrm{Si})-(\mathrm{Mi} \\
-1,5 \mathrm{Si})\end{array}$ & $0 \%-25 \%$ & $\begin{array}{l}\text { Sangat } \\
\text { kurang }\end{array}$ \\
\hline
\end{tabular}

(Nurkencana, 1986)

\section{Hasil dan Pembahasan}

Kit fluida alternatif dari bahan bahan lingkungan dan mudah didapatkan yang berhasil dibuat oleh tim terdiri dari: (1) alat peraga kapal selam sederhana. Kapal selam sederhana ini terbuat dari berbagai jenis botol plastik yang disatukan dengan lem sehingga berbentuk kapal selam. Bagian dalam dari kapal selam ini diberi balon untuk zat pengapung. Alat ini mampu memperlihatkan kepada peserta didik bagaimana sebuah kapal selam bisa mengapung, melayang dan tenggelam di air. Hal ini akan memberikan contoh nyata kepada peserta didik sehingga konsep terapung, tenggelam dan melayang dapat dipahami dengan baik.

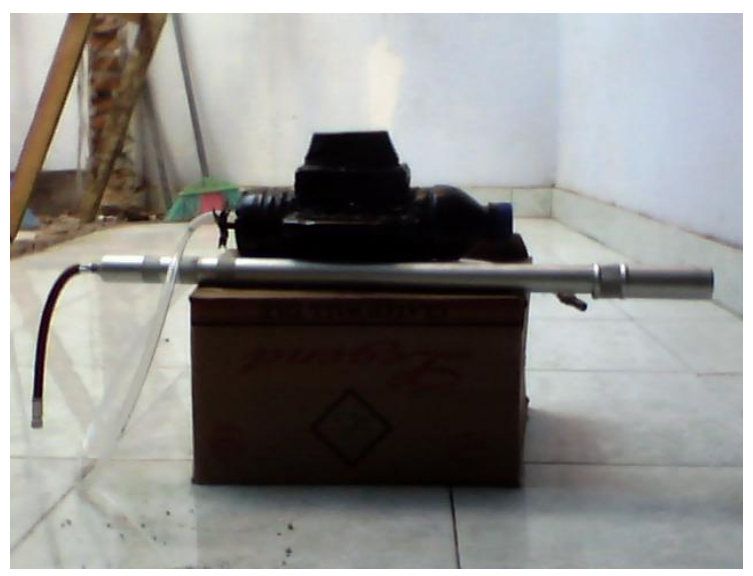

Gambar 1 : Alat Peraga Kapal Selam Sederhana

(2) alat peraga aliran air. Alat peraga ini terbuat dari botol plastik dan selang plastik yang
e-ISSN : 2715-2537

p-ISSN : 2715-2545

menghubungkan dua botol. Alat ini mampu memperlihatkan kepada peserta didik bahwa aliran air akan terjadi bila ada perbedaan tinggi permukaan air. Hal ini akan memberikan contoh nyata tentang konsep aliran air,

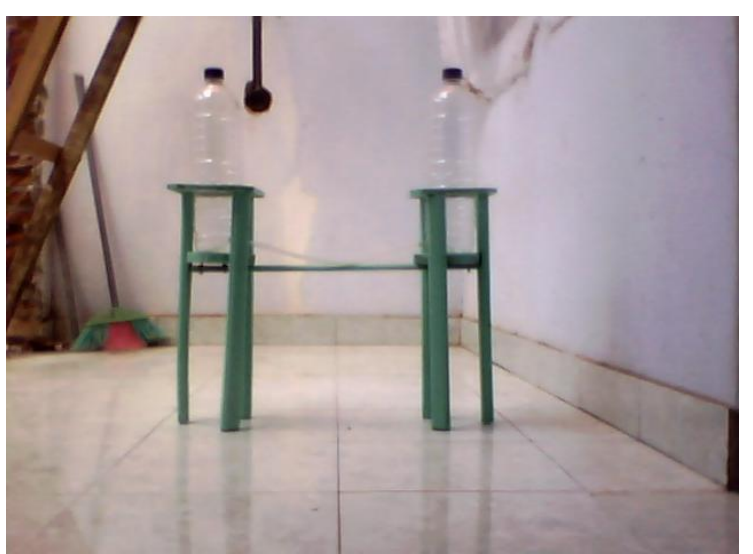

Gambar 2 : Alat Peraga Aliran Air

(3) Pompa air tekanan udara, alat ini terbuat dari botol plastik, air berwarna, dua wadah air transparan, dua potong selang berdiameter $3 \mathrm{~mm}$ dan lumpur. Alat ini digunakan untuk memperlihatkan kepada siswa air yang berada di bawah dapat dinaikkan dengan bantuan tekanan udara.
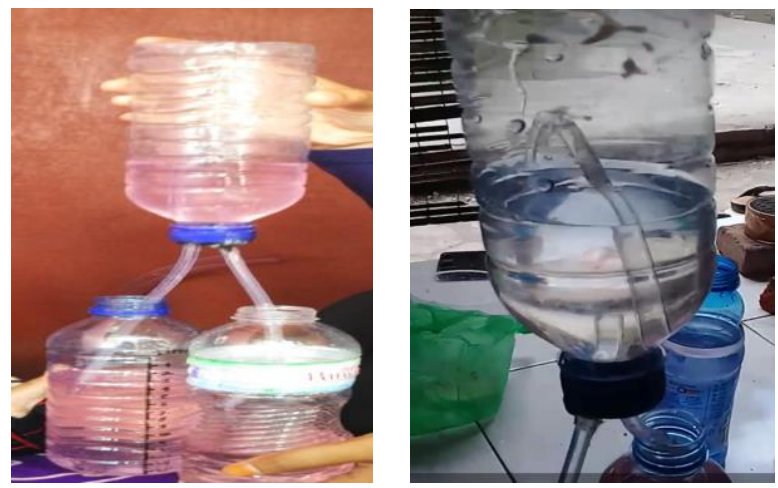

Gambar 3 : Pompa air tekanan udara

(4) barometer botol, alat ini terbuat botol limun, karet balon, sedotan limun, karet gelang, kotak kardus, selotip atau lem dan batang korek api. Ujung sedotan akan bergerak naik tururn tergantung pada perubahan tekanan udara luar. Jika tekanan udara luar bertambah maka karet balon akan tertakan dan melengkung ke dalam botol. Lengkungan karet itu akan menyebabkan ujung sedotan dekat skala akan naik, demikian juga sebaliknya. 
Syahrial Ayub et al, Jurnal Pengabdian Masyarakat Sains Indonesia 2020, 2 (1): 63-68. DOI : https://doi.org/10.29303/ipmsi.v2i1.28

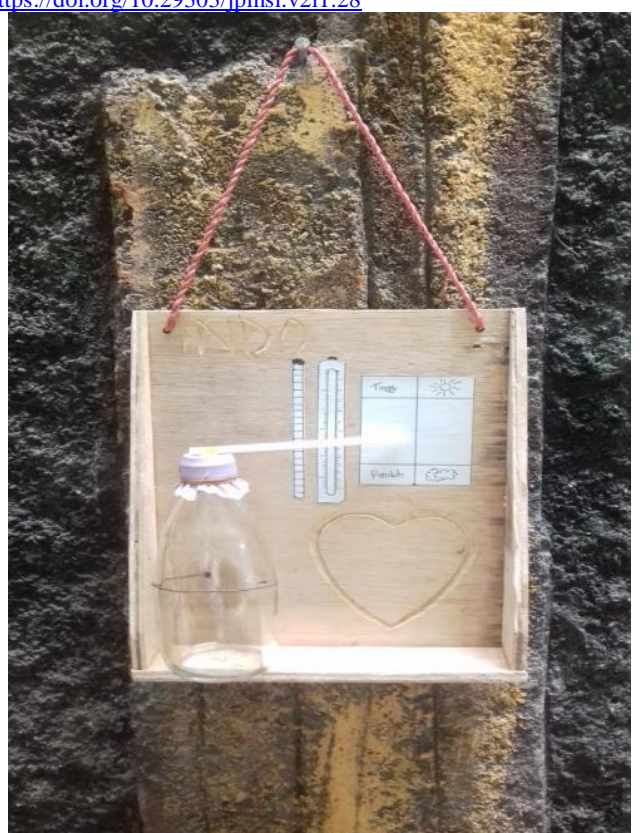

Gambar 4 : barometer botol

(5) Roket udara, alat ini terbuat dari botol plastik, sedotan limun besar, sedotan limun kecil, plastisin, kertas karton dan paku. Alat ini dapat digunakan untuk menanamkan konsep tekanan udara pada siswa. Ketika botol ditekan, tekanan dalam botol naik dan udara keluar menuju sedotan yang terpasang pada tutup botol, akibatnya roket terdorong dan meluncur.

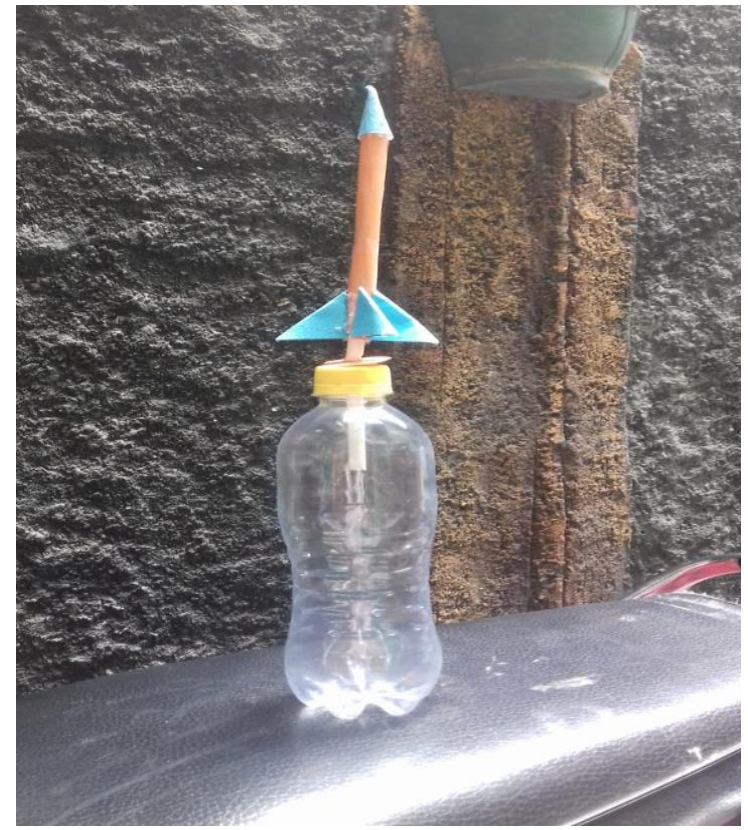

Gambar 5 : roket udara

(6) Helikopter Sederhana, alat ini terbuat dari kertas dan klip penjepit kertas bekas. Cara kerja
e-ISSN $: 2715-2537$

p-ISSN : 2715-2545

helikopter dapat dibandingkan dengan gerak jatuh biji-biji mahoni dari pohonnya. Biji mahoni hanya memiliki satu sayap, tetapi juga dapat berputar pada waktu jatuh. Arah putarnya ditentukan oleh bentuk sayap yang tidak simetris. Helikopter nyata tidak punya sayap, tapi baling-baling yang dapat berputar karena digerakkan oleh motor. Baling-baling tersebut memiliki bentuk tertentu sehingga pada saat berputar helikopter dapat naik.
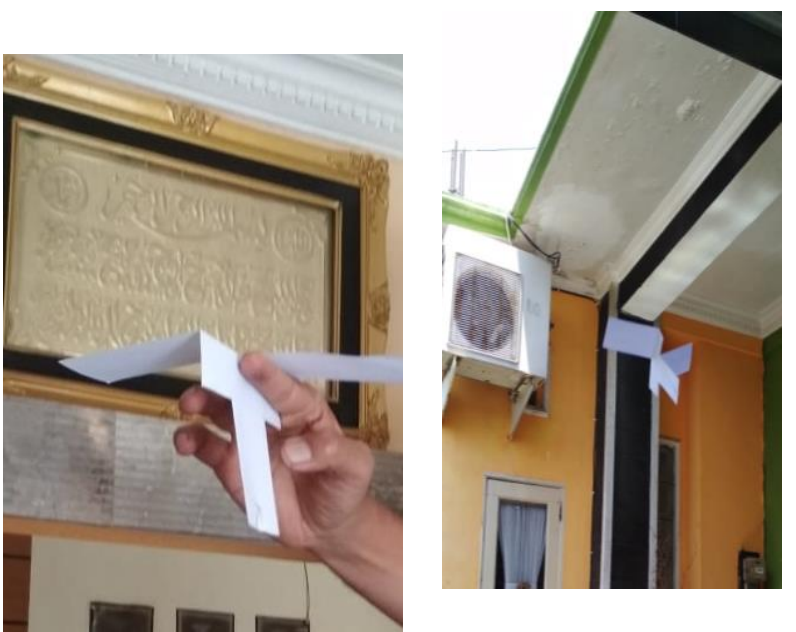

Gambar 6 : helikopter sederhana

Penerapan kit fluida alternatif dalam pembelajaran dapat di masukkan pada kegiatan awal atau kegiatan inti atau kegiatan akhir, sangat tergantung pada tujuan, kreatifitas dan inovasi dari guru yang mengajar. Sebagai contoh, kit fluida alternatif kapal selam sederhana dapat di gunakan sebagai contoh nyata aplikasi pembelajaran fluida pada konsep terapung, tenggelam dan melayang. Kapal selam sederhana ini dapat memberikan contoh nyata bagaimana sebuah kapal selam bisa mengapung, tenggelam dan melayang di air. Pertama tama masukkanlah kapal selam ini ke dalam air atau kolam kecil di halaman sekolah, akibat adanya lubang dan pemberat pada kapal selam maka air masuk saat kapal selam di letakkan. Masukknya air akan menambah berat kapal selam sehingga perlahan ia akan tenggelam. Untuk membuat terapung maka harus dipompakan udara (zat pengapung) ke dalamnya melalui selang yang sudah dibuatkan. Udara ditampung oleh balon yang ada di dalam kapal, dengan pemompaan ini akan menambah ukuran zat pengapung. Ukuran ini bisa kita atur supaya kapal menjadi melayang atau mengapung. Kapal selam sederhana dapat di integrasikan pada pembelajaran dikelas pada kegiatan akhir, yaitu aplikasi dari konsep terapung, 
tenggelam di air sehingga diharapkan siswa diberikan contoh yang agak nyata. Harapannya terjadi peningkatan pemahaman dan ketertarikan pada matapelajaran IPA IPA. Kit fluida alternatif yang lain dapat diaplikasikan pada konsep-konsep lainnya sesuai dengan tujuan alat itu dibuat.

Berdasarkan angket respon yang diberikan kepada peserta didik setelah penerapan kit fluida alternatif pada pembelajaran di kelas didapatkan: (1) pembelajaran dan pemahaman materi $78 \%$ sangat setuju, (2) penerapan Kit fluida alternatif $85 \%$ sangat setuju, (3) lembar kerja peserta didik 72 $\%$ sangat setuju dan, (4) evaluasi $70 \%$ sangat setuju. Jadi rata-rata respon peserta didik terhadap penerapan kit fluida alternatif pada pembelajaran di kelas adalah 76,25\% sangat setuju.

\section{Kesimpulan}

Berdasarkan hasil dan pembahasan sebelumnya, maka dapat disimpulkan bimbingan penerapan kit alternatif pada pembelajaran sangat setuju dilakukan pada pembelajaran IPA di sekolah dasar. dan mendapat respon yang baik dari siswa.

\section{Saran}

Berdasarkan hasil kegiatan pengabdian tentang bimbingan penggunaan kit fluida alternatif di SD Negeri 6 Mataram maka tim menyarankan kegiatan seperti ini dilanjutkan secara kontinu pada sekolah sekolah yang lain. Banyak sekolah yang tidak memiliki kit IPA yang dari pemerintah, sehingga kit fluida alternatif ini bisa menjadi pilihan lain bagi guru dalam mengajarkan IPA di sekolah dasar.

\section{Ucapan Terima Kasih}

Pengabdian ini terselenggara berkat rahmat dari Allah SWT dan bantuan dari berbagai pihak, terutama dari Lembaga Pengabdian dan Pengabdian kepada Masyarakat Universitas Mataram dan SD Negeri 6 Mataram. Bersama ini kami tim pengabdian mengucapkan terima kasih atas segala bantuan dan kerjasamanya.

\section{Daftar Pustaka}

e-ISSN : 2715-2537 p-ISSN : 2715-2545

Klinger, Walter. 1997. Survey of Teaching Methods in Natural Sciences Erziehungswiss: Fakultat der Universtat: Erlangen-Nurnbe.

Klinger. (1997). Survei Metoda Pengajaran dalam Ilmu Pengetahuan Alam. Jakarta : SEQIP

Khaerudin. (2002). Model Pembelajaran Suplemen Melalui Permainan Remi IPA. Mataram: Universitas Mataram.

Merriem Webster. (1953). Webster's Dictionary. Miamy Florida: PSI and Ass Inc

Nurkencana, dkk. (1986). Evaluasi Pendidikan. Jakarta: Usaha Offset Print

Semiawan. (1988). Pendidikan Keterampilan Proses. Jakarta: PT Gramedia.

Syahrial A. (2003). Peningkatan Kualitas Proses Belajar Mengajar IPA Melalui Optimalisasi Penggunaan Kit IPA di SLTP Negeri 6 Mataram. Mataram: Lembaga Pengabdian Universitas Mataram.

Syahrial A. (2001). Studi Penggunaan Kit IPA SD di Kodya Mataram. Mataram : Lembaga Pengabdian Universitas Mataram. 